\title{
Usprawnienie przepływu informacji w instytucji sektora publicznego
}

\section{Improving the flow of information in the enterprise}

\section{Streszczenie:}

Niniejsze opracowanie dotyczy badania procesu przepływu pracy w jednostce organizacyjnej resortu Obrony Narodowej. Wyniki analiz systemu zarządzania i przepływów pracy pomiędzy stanowiskami umożliwiły sformułowanie oceny w zakresie:

- diagnozy - wykrycie nieprawidłowości i słabych punktów procesu przepływu pracy umożliwiającego modyfikację procedur oraz podjęcie działań korygujących wykryte problemy,

- definiowania rozbieżności - świadomość wyższej kadry menadżerskiej dotycząca obszaru komunikacji diametralnie różniąca się od doświadczeń podległych pracowników,

- kształtowania - zadowolenie z procesu przepływu pracy zależy od możliwości wyrażania opinii pracowników oraz uwzględniania ich w opracowaniu propozycji usprawnień,

- wyjaśniania - poczucie doinformowania jest wynikiem uświadomienia pracowników i kadry zarządzającej, że najdogodniejszym źródłem informacji jest bezpośredni przełożony,

- usprawniania - ocena implementacji rozwiązań będących zaleceniami poprzedniego audytu oraz utrzymywania działań korygujących i zapobiegających zakłóceniom gwarantuje sprawnie działający system przepływu pracy.

Zgodnie z zasadą ciągłego doskonalenia ocena funkcjonowania przepływu pracy w badanej instytucji stała się również narzędziem umożliwiającym poprawę funkcjonujących procedur i procesów.

Słowa kluczowe: przepływ pracy 
Mirosław Dąbrowski - Usprawnienie przepływu informacji...

\section{Abstract:}

The study concerns the study of the workflow process in the organizational unit of the Ministry of National Defense. The results of analyzes of the management system and workflows between the positions made it possible to formulate an assessment in the scope of:

- diagnoses - detection of irregularities and weaknesses in the workflow process that allow modification of procedures, and taking corrective action for detected problems,

- defining discrepancies - the awareness of the top management of the area of communication is radically different from the experience of subordinate employees,

- shaping - satisfaction with the workflow process depends on the possibility of expressing employees' opinions and taking them into account when developing improvement proposals,

- explanation - the sense of information is the result of making employees and management aware that the most useful source of information is the immediate supervisor,

- improvement - evaluation of the implementation of solutions that are recommendations of the previous audit and maintaining corrective and preventive measures of disruptions is ensured by an efficient workflow system. In accordance with the principle of continuous improvement, the assessment of the functioning of the work flow in the audited institution has also become a tool enabling the improvement of functioning procedures and processes.

Keywords: workflow

\section{Wprowadzenie}

Ministerstwo Obrony Narodowej skupia w swych strukturach współpracujące ze sobą instytucje, departamenty, wydziały itd. Funkcjonowanie wspomnianych jednostek organizacyjnych oparte jest o przepływ dokumentów wykonawczych będących podstawą rozpoczęcia lub zakończenia każdego wewnętrznego procesu. Na przestrzeni ostatnich lat zauważyć można transformację wielu procedur, procesów oraz narzędzi oddziałujących na kulturę pracy. Rozwój technologiczny dostarcza możliwości, które determinują implementację nowych rozwiązań w płaszczyznach zarządzania zasobami, procesami oraz przepływem pracy i informacji. Do napisania niniejszej pracy zainspirowała 
mnie chęć zbadania właściwego wykorzystania potencjału personelu i narzędzi wspierających przepływ pracy w instytucji państwowej.

Celem niniejszego opracowania jest opis oceny funkcjonowania przepływu pracy w instytucji podległej Ministerstwu Obrony Narodowej, służąca kompleksowej diagnozie przydatności wykorzystywanych systemów wspomagających wykonywanie obowiązków służbowych. Ocenę przeprowadzono wykorzystując procedurę audytu, używając autorskich narzędzi badawczych. Szczególną uwagę zwrócono na współdziałanie i przepływ informacji jako czynniki niezbędne do realizacji określonych wartości stanowiących cel dążenia zarówno pojedynczej jednostki, jak i grupy współpracujących osób ${ }^{1}$.

Realizacja tak zdefiniowanego celu pracy wymaga rozwiązania następujących problemów badawczych:

1. Określenia istoty zarządzania przepływem pracy.

2. Analizy organizacji przepływu pracy w badanej jednostce Ministerstwa Obrony Narodowej.

3. Sformułowania koncepcji badania (audytu) przepływu pracy służącego kompleksowej diagnozie przydatności wykorzystywanych systemów wspomagających wykonywanie obowiązków służbowych.

4. Przeprowadzenia audytu na podstawie opracowanego narzędzia diagnostycznego.

5. Analizy wyników badań.

6. Opracowania wniosków i zaleceń reorganizacji wybranych obszarów.

\section{Wybrane pojęcia dotyczące przepływu pracy}

Skupiając się na zagadnieniu przepływu pracy, należy zdać sobie sprawę z czynników składowych takich, jak: przygotowanie, planowanie oraz sterowanie procesami na poszczególnych etapach, w których

\footnotetext{
${ }^{1}$ R. Winkler, Zarządzanie komunikacją w organizacjach zróżnicowanych kulturowo, Kraków 2008, s. 473.
} 
Mirosław Dąbrowski - Usprawnienie przepływu informacji...

za pomocą przyjętych metod modeluje się produkty, środowisko wewnętrzne i zewnętrzne ${ }^{2}$. W literaturze przedmiotu dominuje termin „workflow”, który powstał przez połączenie dwóch wyrazów pochodzących z języka angielskiego: work - praca oraz flow - przepływ ${ }^{3}$. Teoretycznie dosłowne tłumaczenie nie powinno sprawiać kłopotów, jednak w rzeczywistości pod pojęciem tym kryje się obieg zadań, polityka zarządzania dokumentami, przepływem informacji lub przebieg pracy. W kwestiach związanych z oprogramowaniem wspierającym procesy zarządzania zaobserwować można stosowanie pojęcia „system workflow” lub skrót „WFM” pochodzący od angielskich pojęć workflow management ${ }^{4}$ (zarządzanie przepływem pracy).

Organizacja WfMC (ang. Workflow Management Coalition) zajmująca się między innymi standaryzacją pojęć związanych z procesami związanymi z przepływem pracy w organizacjach w 1999 r. opracowała najczęściej cytowaną definicję, która brzmi następująco: „Workflow jest częściową lub pełną automatyzacją procesu biznesowego, podczas którego informacje, zadania i dokumenty są przenoszone pomiędzy uczestnikami procesu w celu wykonania działań zgodnych ze zbiorem sformalizowanych zasad". Ilustrację tej definicji przedstawia Rysunek 15 .

Proces biznesowy jest zbiorem działań lub procedur realizujących określony cel przedsiębiorstwa ${ }^{6}$. Systemy workflow zarządzają zdefiniowanym przepływem pracy, zwykle poprzez użycie oprogramowania złożonego z modułów współdziałających z użytkownikami i interpretujących zachodzące procesy.

2 Z. J. Klonowski, Systemy informatyczne zarządzania przedsiębiorstwem. Modele rozwoju i właściwości funkcjonalne, Wrocław 2004, s. 114.

3 B. Gawin, Systemy informatyczne w zarządzaniu procesami workflow, Warszawa 2015.

${ }^{4}$ Ibidem.

5 Z. Martyniak, Teoretyczne podstawy systemów workflow, „Informatyka” 2000, nr 3, s. 37.

6 Ibidem, s. 36-37.

${ }^{7}$ M. Ćwiklicki, Podstawy systemów workflow, Kraków 2006, s 10. 
Rysunek 1. Graficzna interpretacja definicji przepływu pracy (ang. workflow)

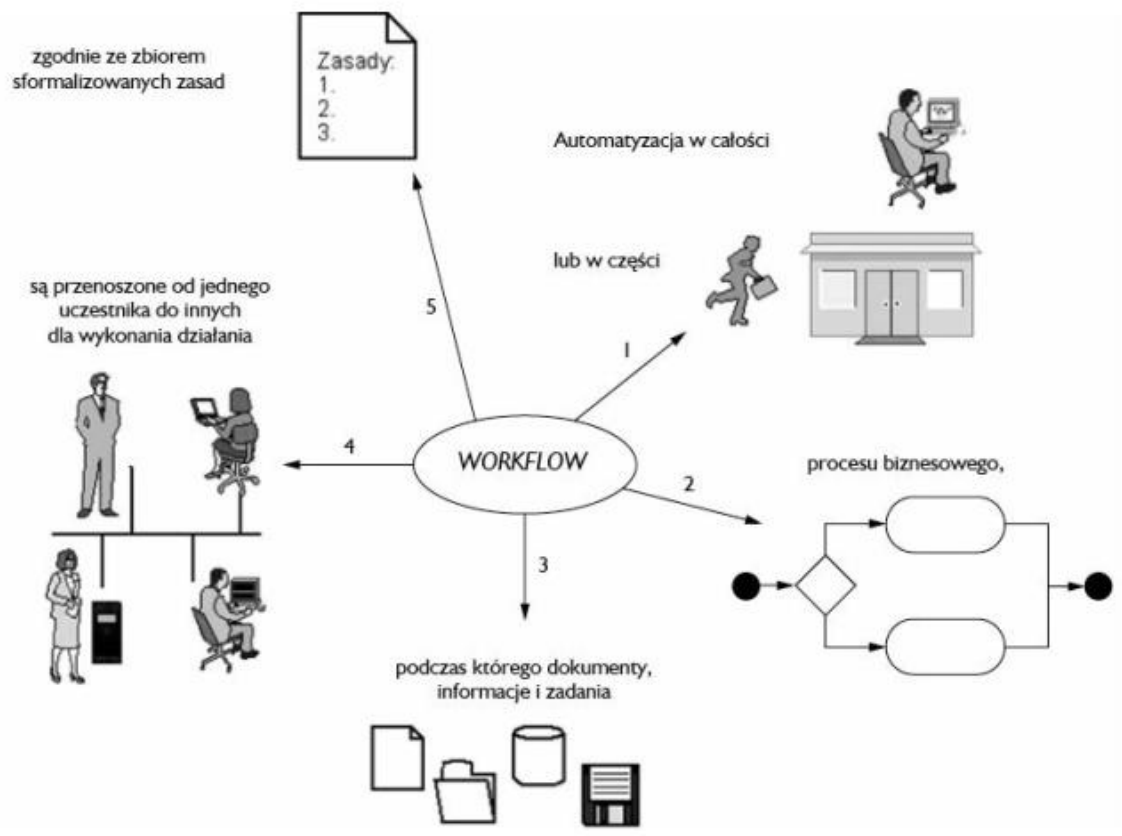

Źródło: B. Gawin, Systemy informatyczne w zarządzaniu procesami workflow, Warszawa 2015

Uczestnikami procesu biznesowego są zasoby realizujące przypisane do nich zadania. Zasoby, którymi są między innymi ludzie, maszyny, komputery i oprogramowanie, są identyfikowane na etapie projektowania lub analizy procesu. Przypisanie działań następuje poprzez stworzenie dla określonego zasobu listy zadań do realizacji (ang. worklist $^{8}$ ). W organizacji zarządzanej procesowo podstawowym ogniwem są pracownicy postępujący zgodnie $\mathrm{z}$ wyznaczonymi algorytmami procesów ${ }^{9}$.

${ }^{8}$ Workflow Management Coalition. Terminology \& Glossary, s. 20, https://www.yumpu.com/en/document/read/4582836/workflow-managementcoalition-terminology-glossary

9 P. Grajewski, Organizacja procesowa, PWE, Warszawa 2007, s 27. 
Mirosław Dąbrowski - Usprawnienie przepływu informacji...

\section{Procesy biznesowe}

Rozwój technologii informacyjno-komunikacyjnych na przestrzeni ostatniej dekady zdominował obszar zarządzania procesami wielu korporacji i przedsiębiorstw.

Analiza różnych definicji procesu biznesowego przeprowadzona przez P. Grajewskiego uwypukliła tezę przyczynowo- skutkowej zależności między działaniami w procesie. Oznacza to zależność końcowego wyniku procesu od wyników zachodzących po sobie działań zgodnie ze schematem zamieszczonym na Rysunku 2.

Rysunek 2. Proces jako sekwencja logicznie uporządkowanych czynności

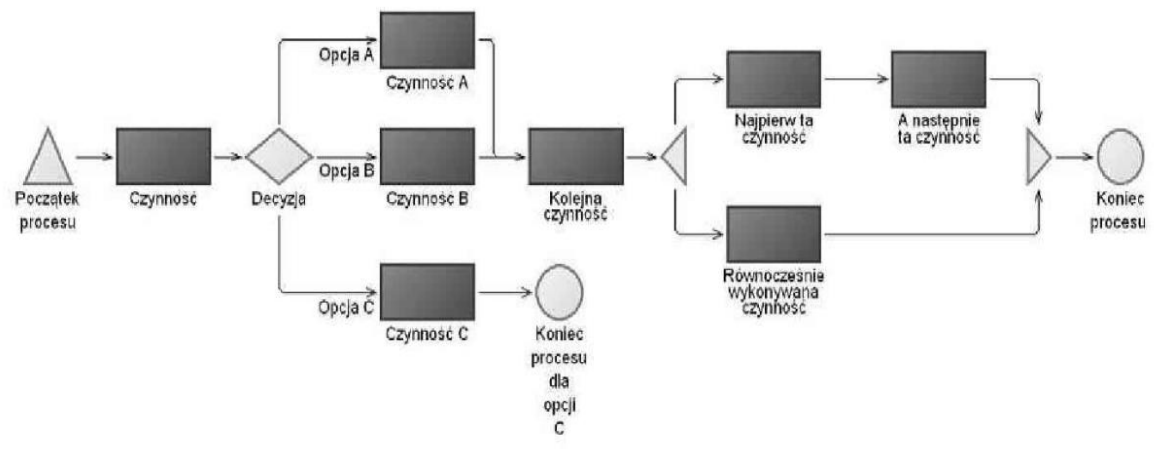

Źródło: Materiały promocyjne firmy BOC Polska Sp zo.o.

Podobną definicję podaje norma ISO 9000, w której proces to: „Zestaw działań wzajemnie powiązanych lub wzajemnie oddziałujących, które przekształcają wejścia w wyjścia"10.

Amerykański statystyk, William Edwards Deming w jednym z czternastu postulatów dotyczących metod zarządzania wykazał, że 85\% przyczyn niezadowolenia klientów jest spowodowane brakami organizacji procesów i systemów pracy, a nie umiejętnościami pracowników. Rolą menadżerów jest optymalizacja procesów, a nie nękanie pracow-

10 PN-EN ISO 9000:2006. Systemy zarządzania jakościq - Podstawy i terminologia. 
ników. Powyższa teza może stać się kluczem do rozwiązania wielu problemów organizacyjnych poprzez identyfikację wewnętrznych procesów oraz ich analizę pod kątem usprawnienia i modyfikacji.

Przytoczone wnioski stanowią wprowadzenie do określenia metody zarządzania przedsiębiorstwem za pośrednictwem zarządzania procesami.

Aby podejmować właściwe decyzje, ludzie potrzebują danych, informacji i wiedzy. Z drugiej strony podejmując decyzje, gromadzą dane, wiedzę i informacje. W powyższych zależnościach kryje się zagrożenie, ponieważ po pewnym czasie, ze względu na zwiększającą się ilość danych, coraz trudniej pracownikom dotrzeć do niezbędnych zasobów. Generuje to potrzebę zbudowania systemów, których architektura oparta jest o procesy ${ }^{11}$.

Bez względu na to, czy procesy przebiegające $\mathrm{w}$ organizacji zostały uprzednio zidentyfikowane i opisane, czy nie, faktem jest, że niektóre $\mathrm{z}$ nich są niezauważane ze względu na marginalny wpływ na funkcjonowanie zespołów ludzkich ${ }^{12}$. Podejście procesowe uznawane jako jedna z podstaw zarządzania zawiera w sobie szereg definicji zawartych w dokumentach normatywnych dotyczących jakości ${ }^{13}$. Proces posiada swój cel, który powinien być dopasowany do zamierzonego efektu ${ }^{14}$. Proces sam w sobie rozumiany jest jako zbiór następujących po sobie operacji (czynności) wzajemnie ze sobą powiązanych i oddziałujących na siebie. Poza kwestiami identyfikowania i systematyzowania procesów należy zwrócić uwagę na przestrzeń pomiędzy zachodzącymi po sobie operacjami wypełnioną informacją zawierającą sygnał zakończenia i zainicjowania kolejnego etapu.

${ }^{11}$ K. Kania, Analiza procesów $w$ adaptatywnych $w$ systemach workflow, Katowice 2015, s. 309. 2011.

13 Por. normy ISO 9000:2000 i ISO 9001:2000.

14 Ibidem. 
Mirosław Dąbrowski - Usprawnienie przepływu informacji...

\section{Wpływ komunikacji na przepływy pracy}

Termin „komunikacja” pochodzi od łacińskiego rzeczownika communio oznaczającego poczucie łączności oraz czasownika communicare (udzielić komuś wiadomości, uczynić wspólnym, połączyć) ${ }^{15}$. Komunikowanie jest jednym z procesów warunkujących egzystencję zbiorowisk ludzkich towarzyszącym każdej dziedzinie życia. Zagadnienia dotyczące komunikacji w przedsiębiorstwie są elementem kultury organizacyjnej wpływającym na efektywność pracy oraz funkcjonowanie organizacji. Przekazywanie poleceń, procedur, komunikatów czy informacji jest fundamentem wszelkich procesów przepływu pracy ze względu na pochłaniany czas oraz gwarancję koordynacji pracy zespo$ł_{\text {łowej }}{ }^{16}$. Analizując literaturę przedmiotu, można znaleźć wiele zbieżności dotyczących rozumienia pojęcia komunikacji. Organizacja komunikacji w przedsiębiorstwie również zawiera wiele interpretacji związanych powodem inicjacji procesu, jego formą, przebiegiem oraz pożądanym i osiągniętym skutkiem. Wybrane opinie autorów opracowań poruszających rozważane zagadnienie zestawiono w Tabeli 1.

Komunikacja zatem z jednej strony jest procesem samym w sobie, $\mathrm{z}$ drugiej strony natomiast jest nierozłącznym elementem procesów zachodzących podczas pracy grupowej ${ }^{17}$. Zasadnym jest zatem przeprowadzenie analizy procesów zachodzących wewnątrz firmy pod kątem komunikacji wewnętrznej. Dostarczy to informacji dotyczących wyników pracy zarówno pojedynczych jednostek, jak i zespołów ${ }^{18}$.

Procesem efektywnej komunikacji jest przekazywanie informacji zrozumiałej dla wszystkich jego uczestników, ponieważ:

- umożliwia codzienne funkcjonowanie,

- umożliwia zespołowe podejmowanie decyzji,

- zwiększa efektywność działań,

15 T. W. Nowacki, K. Korabiowska-Nowacka, B. Baraniak, Nowy słownik pedagogiki pracy, Warszawa 1999.

16 J. Stankiewicz, Komunikowanie się w Organizacji, Wrocław 2006, s 13.

17 M. Maciejczak, Zarzq̨dzanie procesami biznesowymi..., op. cit. s.16.

18 R. Winkler, Zarządzanie komunikacją..., op. cit., s. 473. 
- wpływa na stosunki interpersonalne,

- kreuje atmosferę pracy.

Tabela 1. Zestawienie wybranych sposobów określania istoty terminu „komunikacja"

\begin{tabular}{|l|l|}
\hline \multicolumn{1}{|c|}{ Autor } & \multicolumn{1}{c|}{ Wyjaśnienie terminu } \\
\hline J. Eicher19 & „...proces wysyłania i odbierania wiadomości" \\
\hline K. Adams G. J. Galanes 20 & $\begin{array}{l}\text { „Proces tworzenia, nadawania, odbierania i interpretowania } \\
\text { komunikatów między ludźmi" }\end{array}$ \\
\hline J. Cornelissen 21 & $\begin{array}{l}\text { „Wszystkie instrumenty wykorzystywane przez firmę do } \\
\text { porozumiewania się z pracownikami” }\end{array}$ \\
\hline K. Weinsten 22 & $\begin{array}{l}\text { „...przekazywanie innym komunikatów; jest to zarazem } \\
\text { proces (w jaki sposób się komunikuję) i treść (co } \\
\text { przekazuję); w praktyce oba te aspekty są często } \\
\text { nierozłączne" }\end{array}$ \\
\hline B. Sobkowiak23 & $\begin{array}{l}\text { „Komunikacja interpersonalna to wymiana wokalnych, } \\
\text { werbalnych i niewerbalnych sygnałów (znaków) w celu } \\
\text { wzajemnego zrozumienia się stron, a w konsekwencji } \\
\text { lepszego współdziałania”. }\end{array}$ \\
\hline
\end{tabular}

Źródło: Opracowanie własne

Sprawna komunikacja posiada również wpływ na zapewnienie ciągłości działania organizacji oraz realizacji kluczowych procesów. Jej efektywność jest współzależna od nadawcy, narzędzia komunikacyjnego, odbiorcy, interakcji i skutku wywołanego komunikatem.

19 J. Eicher, Sztuka komunikowania się, Łódź 1995, s. 23.

${ }^{20}$ K. Adams, G. J. Galanes, Komunikacja w grupach, Warszawa 2008, s. 63.

21 J. Cornelissen, Corporate Communications Theory and Practice, Londyn 2004, s. 189.

${ }^{22}$ K. Weinstein, Komunikowanie się, [w:] D. M. Steward (red.), Praktyka kierowania, Warszawa 1994, s. 323-324.

23 B. Sobkowiak, Interpersonalne i grupowe komunikowanie się $w$ organizacji, Poznań-Wrocław 2005, s. 17-18. 
Mirosław Dąbrowski - Usprawnienie przepływu informacji...

\section{Metoda, technika i narzędzia badawcze}

Metoda badawcza określana jest jako „system założeń i reguł pozwalających na uporządkowanie praktycznej lub teoretycznej działalności, aby można było osiągnąć dany cel" 24 . Termin ten należy definiować jako „ogólne, niedostatecznie uszczegółowione sposoby dochodzenia do uzasadnionych i sprawdzonych stwierdzeń na temat zjawisk i procesów"25. Metoda badawcza jest systematycznie stosowanym sposobem prowadzenia badań, „to znaczy w danym przypadku z intencją zastosowania go także przy ewentualnym powtórzeniu się analogicznego zadania"26.

Niniejsza praca wykorzystuje metodę sondażu diagnostycznego, w którym informacje dotyczące badanych obszarów pozyskano poprzez wykorzystanie opracowanych kwestionariuszy badawczych. Użyta metoda pozwala na zestawienie statystyk precyzujących cechy, zachowania i postawy badanej zbiorowości na podstawie opinii wyselekcjonowanych respondentów ${ }^{27}$. Brak możliwości dotarcia do wszystkich uczestników procesów przepływu pracy, specyfika wykonywanych obowiązków lub krótki staż pracy zawęziły grupę respondentów.

Technika badawcza definiowana jest jako „sposób zbierania materiałów oparty na dokładnych i jasnych dyrektywach, weryfikowanych w badaniach różnych nauk społecznych" ${ }^{28}$. Klasyfikując metody i techniki badawcze, należy zauważyć, że „metoda badań odnosi się do ogólnych dyrektyw czy norm (reguł) postępowania badawczego, to jest obowiązujących bez względu na cel, jakiemu ma ona służyć i warunki, w jakich się ją stosuje. Technika badań natomiast jest tożsama z bliżej skonkretyzowanymi wskazaniami, określającymi możliwie dokładnie i szczegółowo przebieg organizowanego za jej pomocą procesu badawS. 46.

${ }^{24}$ J. Sztumski, Wstęp do metodologii i technik badań społecznych, Katowice 2010,

${ }^{25}$ M. Łobocki, Wprowadzenie do metodologii badań pedagogicznych, Kraków 2012, s. 115.

26 W. Zaczyński, Praca badawcza nauczyciela, Warszawa 2011, s. 18.

27 E. Babbie, Badania społeczne w praktyce, Warszawa 2013, s. 73-74.

28 M. Łobocki, Wprowadzenie..., op. cit., s. 140. 
czego. Podporządkowana jest z reguły określonej metodzie badań i pełni wobec niej rolę służebną. Inaczej mówiąc, technika badawcza jest zawsze pewną uszczegółowioną odmianą metody badań. Ta z kolei może w zasadzie poszczycić się kilkoma różnymi technikami badań"29.

Techniki badawcze są skorelowane z narzędziami badawczymi, a więc „wszelkiego typu pomocami, które umożliwiają przeprowadzenie oraz utrwalenie pomiaru zjawiska będącego przedmiotem badań"30. Wykorzystana technika ankiety dostarczyła szeregu odpowiedzi na pytania zawarte w kwestionariuszach, czyli „arkuszach z wydrukowanymi pytaniami i wolnymi miejscami na wpisanie odpowiedzi, wśród których respondenci wybierają te, które uważają za prawdziwe.

\section{Charakterystyka respondentów}

Grupa respondentów przedstawiona graficznie na Wykresie 1 obejmowała siedemdziesięciu pięciu pracowników (100\%) wykonujących obowiązki służbowe w badanej instytucji. Wyselekcjonowana została spośród przedstawicieli szczebli kierowniczych (7 osób - 9\%), zarządzających (30 osób - 40\%) oraz pracowniczych (38 osób - 51\%).

Wykres 1. Struktura ankietowanych wg kryterium pełnionej funkcji

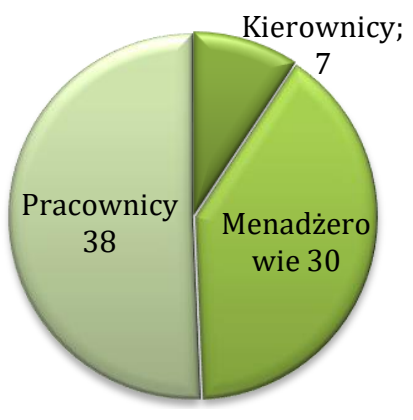

Źródło: Opracowanie własne

29 Tamże, s. 217.

30 W. Puślecki, Metody badań pedagogicznych, Toruń 2012, s. 12. 
Na podstawie danych pozyskanych z metryczki respondenta grupę badanych podzielono według dwóch kryteriów. Pierwszym z nich był przedstawiony na wykresie 2 podział na żołnierzy i pracowników cywilnych.

Wykres 2. Struktura ankietowanych wg kryterium stosunku pracy

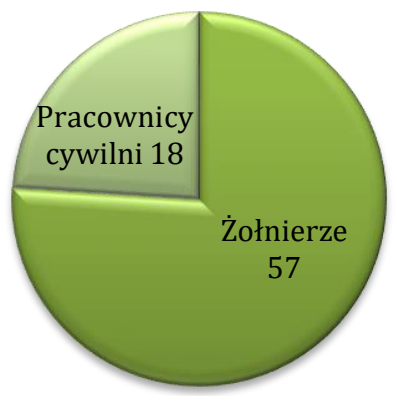

Źródło: Opracowanie własne

Badana grupa liczyła pięćdziesięciu siedmiu żołnierzy zawodowych, co stanowiło siedemdziesiąt sześć procent ankietowanych. Pozostałą, dwudziestoczteroprocentową grupę badanych stanowili pracownicy cywilni. Dane zebrane z metryczek respondentów umożliwiły również podział ankietowanych (Wykres 3) ze względu na kryterium płci, ponieważ grupa badanych liczyła sześćdziesięciu sześciu mężczyzn (88\%) oraz dziewięć kobiet (12\%).

Wykres 3. Struktura ankietowanych wg kryterium płci

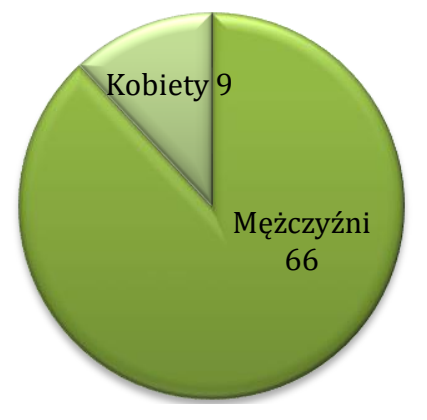

Źródło: Opracowanie własne 
Przedstawione dane stanowiły podstawę do sformułowania zamieszczonych wcześniej hipotez dotyczących zależności postrzegania problemów towarzyszących przepływowi pracy od płci, zajmowanych stanowisk służbowych oraz formy zatrudnienia (żołnierz zawodowy, pracownik cywilny).

\section{Ocena przepływów pracy i informacji}

Pierwsza część kwestionariusza ankietowego poświęcona została ocenie przepływów informacji i pracy w badanej instytucji (Wykres 4). W pierwszym pytaniu dotyczącym przepływu informacji pomiędzy przełożonym a podwładnym trzydziestu sześciu ankietowanych (48\%) oceniło proces bardzo dobrze, trzydziestu (40\%) dobrze, sześciu (8\%) przeciętnie, trzy osoby źle (4\%). Bardzo źle nie ocenił nikt $(0 \%)$.

Wykres 4. Wyniki oceny przepływu informacji pomiędzy przełożonym a podwładnym

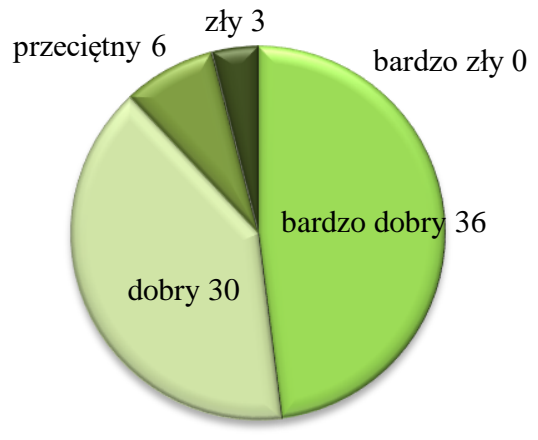

Źródło: Opracowanie własne

Drugie pytanie zawarte $\mathrm{w}$ ankiecie dotyczyło oceny respondentów zagadnienia przepływu informacji pomiędzy podwładnym a przełożonym. Zestawienie uzyskanych odpowiedzi przedstawione $\mathrm{w}$ formie 
Mirosław Dąbrowski - Usprawnienie przepływu informacji...

graficznej na Wykresie 5. wskazuje, że dwadzieścia osiem osób (37\%) oceniło podmiotowy proces na poziomie bardzo dobrym, czterdzieści dwie osoby (56\%) dobrym i pięć osób (7\%) na poziomie przeciętnym. Jest to wynik ilości wykonywanych zadań służbowych oraz częstotliwości kontaktów opisany w dalszej części niniejszej pracy.

Wykres 5. Wyniki oceny przepływu informacji pomiędzy podwładnym a przełożonym

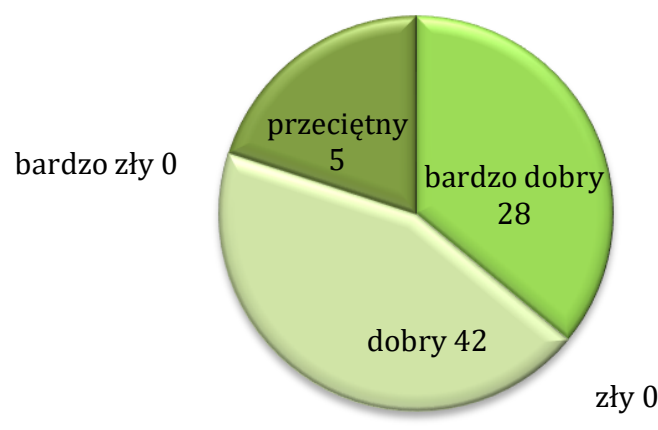

Źródło: Opracowanie własne

Następnie ankietowanych zapytano o ocenę przepływu informacji pomiędzy żołnierzami a pracownikami cywilnymi (Wykres 6). Trzydziestu trzech ankietowanych (44\%) oceniło powyższy proces w stopniu dobrym, dwudziestu siedmiu (36\%) w stopniu bardzo dobrym i piętnastu (20\%) na poziomie przeciętnym. 
Wykres 6. Wyniki oceny przepływu informacji pomiędzy żołnierzami a pracownikami cywilnym

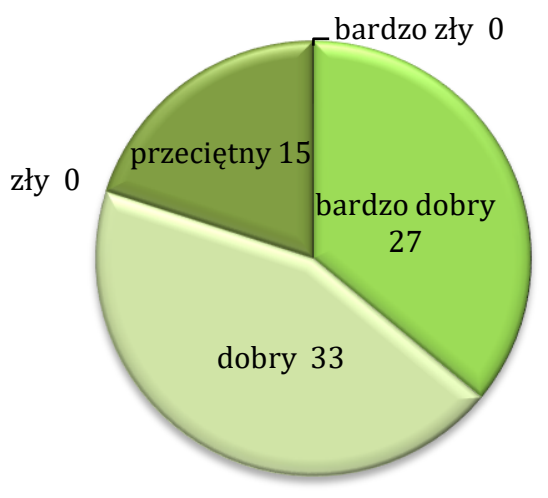

Źródło: Opracowanie własne

Przepływ informacji pomiędzy komórkami (Wykres 7) ośmiu (11\%) ankietowanych oceniło w stopniu bardzo dobrym, dwudziestu siedmiu (27\%) w stopniu dobrym, trzydziestu dziewięciu (52\%) oceniło przeciętnie i ośmiu (11\%) niesatysfakcjonująco. Wynika to z faktu nierównomiernego obciążenia pracą, specyfiką wykonywanych zadań oraz częstymi wyjazdami szkoleniowymi i treningami. Respondenci wskazali również problem związany z zawyżoną samooceną pracowników niektórych działów, która niekorzystnie wpływa na stosunki interpersonalne, a tym samym na przepływ informacji i realizację zadań skupiających zespoły specjalistów. Problemy związane z przepływem informacji są zgłaszane przez pracowników, co spotyka się z reakcją służącą poprawie zaobserwowanych odstępstw od przyjętych norm współpracy. 
Mirosław Dąbrowski - Usprawnienie przepływu informacji...

Wykres 7. Wyniki oceny przepływu informacji pomiędzy komórkami

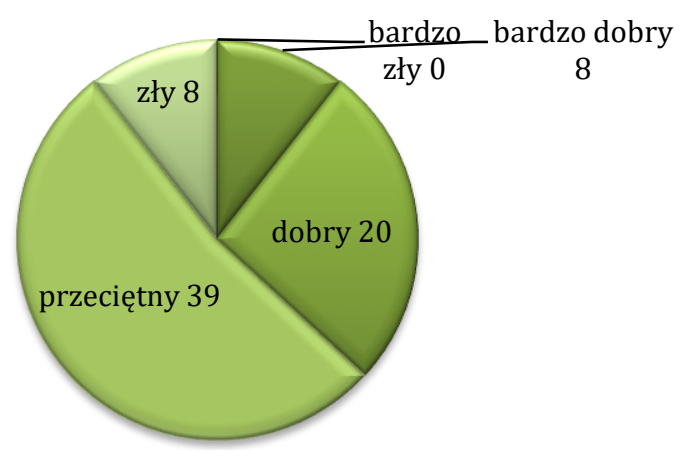

Źródło: Opracowanie własne

Pytanie: „Czy działania w obszarze przepływu informacji oparte są na diagnozie opinii i potrzeb żołnierzy i pracowników?” dostarczyło odpowiedzi zawartych na Wykresie 8.

Wykres 8. Wyniki oceny działań w obszarze przepływu informacji względem potrzeb żołnierzy i pracowników

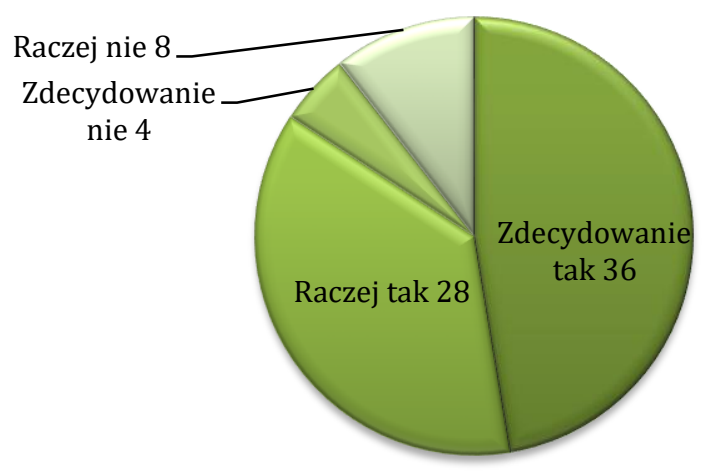

Źródło: Opracowanie własne

Trzydziestu sześciu (48\%) ankietowanych uważa, że systemy przepływu informacji są reorganizowane adekwatnie od zgłaszanych potrzeb. Dwudziestu ośmiu (37\%) respondentów uważa modernizację 
procesów za możliwą (po sprecyzowaniu preferencji i potrzeb), ośmiu (11\%) wątpi w możliwość reorganizacji, natomiast czterech (5\%) uważa za niemożliwą.

Pytanie dotyczące formy oraz środka przepływu pracy i informacji pomiędzy pracownikami dostarczyło danych przedstawionych na Wykresie 9. Czterdziestu czterech ankietowanych (59\%) wykazało dominację przepływu bezpośredniego (odprawy, spotkania, narady, rozmowy), trzydziestu jeden (41\%) zadeklarowało przepływ pośredni (SI Arcus, poczta elektroniczna) ze względu na specyfikę wykonywanych zadań (opracowywanie dokumentów planistycznych, sprawozdawczych, rozliczeniowych wniosków), które podlegają archiwizacji.

Wykres 9. Wyniki oceny form przepływu pracy w Jednostce

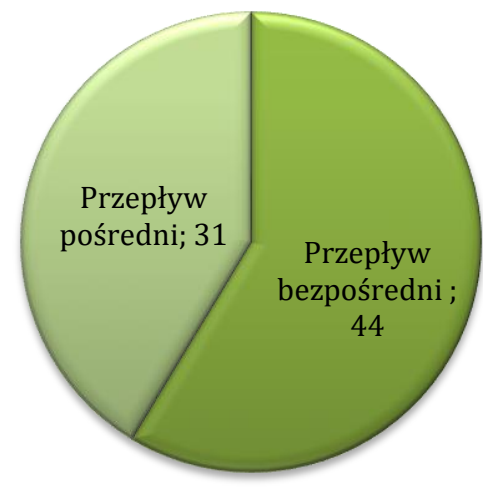

Źródło: Opracowanie własne

Respondenci badanej instytucji przekazują między sobą informacje, wykorzystując szerokie spektrum form komunikacji przedstawionych na Wykresie 10. Najczęściej użytkowanym kanałem przepływu informacji jest telefonia komórkowa (23\%), następnie telefonia stacjonarna (17\%), nieformalne rozmowy współpracowników (14\%), odprawy z podwładnymi (9\%), odprawy kierownictwa (8\%), system elektro- 
Mirosław Dąbrowski - Usprawnienie przepływu informacji...

nicznego obiegu dokumentów SI ARCUS (8\%), poczta elektroniczna Milnet-Z (6\%), wideokonferencje (6\%), E-mail Milnet- I (5\%), tablice informacyjne (2\%), zasoby dysku sieciowego (1\%).

W kwestii dotyczącej nieformalnych narzędzi komunikacji dominuje wykorzystanie telefonu komórkowego ze względu na jego dostępność oraz zaimplementowaną listę kontaktów. Łatwość nawiązania rozmowy telefonicznej jest czynnikiem ułatwiającym komunikację obejmującą przekaz krótkich informacji lub komunikatów. Powoduje to jednak częste odstępstwa od wymagań formalnego obiegu pracy w przypadku problemów z logowaniem do systemów teleinformatycznych lub zgłoszeń awarii sprzętu.

Wykres 10. Główne kanały przepływu informacji w Jednostce

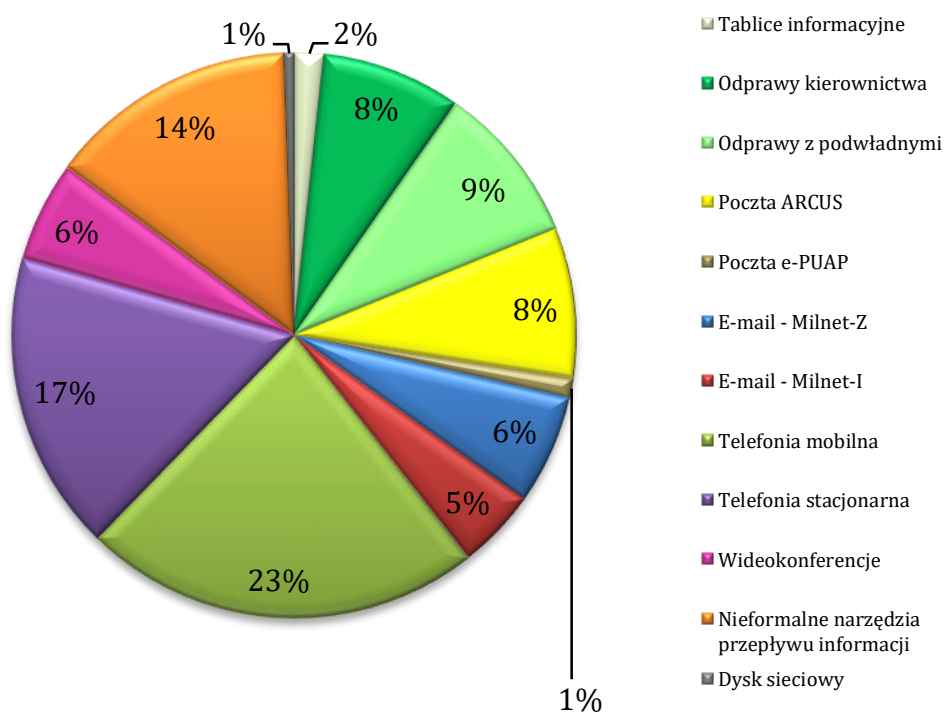

Źródło: Opracowanie własne

Dedykowanym kanałem przekazywania komunikatów dotyczących usterek jest formularz zgłoszeniowy platformy „Help-Desk” będący usługą sieci korporacyjnej MILNET-Z. Pomijanie wspomnianego kana- 
łu dezorganizuje harmonogram prac personelu teleinformatycznego oraz zaniża statystyki rozliczeń wykonywanych czynności. Pracownicy kilkakrotnie oświadczyli, że zdarza im się nie odbierać połączeń telefonicznych w przypadku dużego obciążenia pracą lub obowiązkiem pozostawiania telefonów komórkowych na zewnątrz stref, w których używanie urządzeń rejestrujących obraz lub dźwięk jest zabronione.

Rzadkie wykorzystywanie wideokonferencji wynika głównie ze specyfiki wykonywanych obowiązków, okrojonego dostępu do wideotelefonów oraz umiejętności zestawienia wideokonferencji. Podkreślić należy, że nieliczne z wykorzystywanych telefonów IP umożliwiają zestawienie połączenia wideo (pomiędzy maksymalnie trzema abonentami). Organizacja konferencji telefonicznej z udziałem większej ilości rozmówców wymaga rezerwacji połączenia za pośrednictwem portalu www.meetingplace. Organizator konferencji jest zobligowany do podania daty, godziny, numerów telefonów biorących udział oraz adresów poczty elektronicznej w przypadku zamiaru udostępniania prezentacji lub pulpitu komputera. Wideokonferencje są używane głównie na szczeblach dowódczych oraz przez pion teleinformatyczny w przypadkach wdrożeń systemów rozproszonych, obejmujących swym zasięgiem zbiór jednostek stacjonujących w oddalonych od siebie lokalizacjach.

Informacje zamieszczane na tablicach ogłoszeń nie są związane z wykonywanymi obowiązkami służbowymi. Powoduje to brak zainteresowania treściami niezwiązanymi z obszarem działalności pracowników.

Ocena wykorzystywanych kanałów przepływu pracy przez ankietowanych dostarczyła wyników zamieszczonych na Wykresie 11. Na ich podstawie możemy stwierdzić, że systemy teleinformatyczne dominują analizowany obszar.

Zestawienie uzyskanych odpowiedzi umożliwiło sformułowanie stwierdzenia, że głównym kanałem przepływu pracy jest system Milnet-Z (32\% ankietowanych) działający w oparciu o infrastrukturę sieci kampusowej (intranet) połączonej z globalną siecią korporacyjną. Ist- 
Mirosław Dąbrowski - Usprawnienie przepływu informacji...

niejący fakt jest wynikiem polityki organizacji pracy w instytucjach resortu Obrony Narodowej, która determinuje wykorzystanie terminali Milnet-Z do realizacji procesów kancelaryjno-biurowych.

Wykres 11. Wartości procentowe wykorzystywanych kanałów przepływu pracy w Jednostce
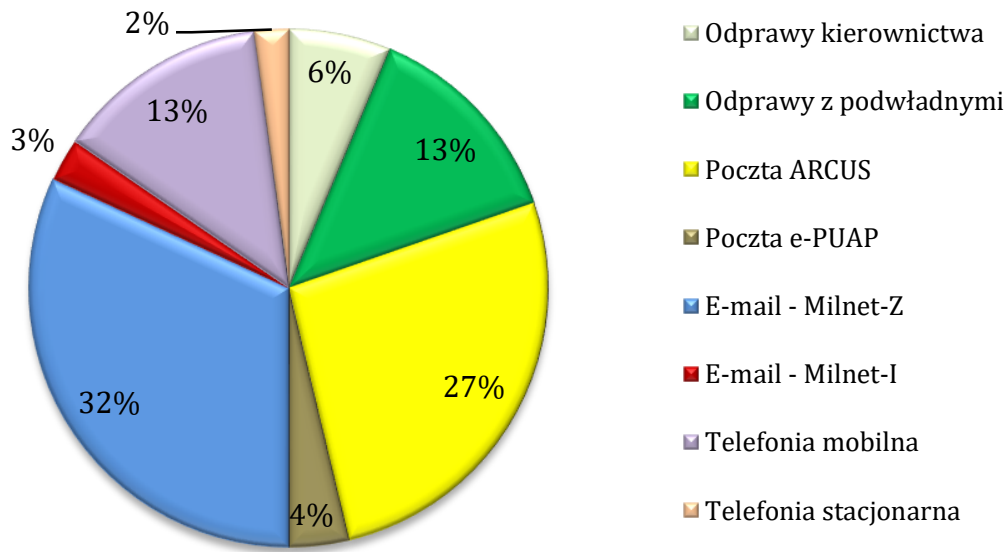

Źródło: Opracowanie własne

Elektroniczny system obiegu dokumentów SI ARCUS (będący składnikiem oprogramowania codziennie użytkowanych terminalach roboczych) jest wykorzystywany przez dwadzieścia siedem procent respondentów. Wyjątek stanowi system e-PUAP Platformy Usług Administracji Publicznej (4\%) umożliwiający komunikację z instytucjami niepodlegającymi resortowi Obrony Narodowej, takimi jak Zakład Ubezpieczeń Społecznych, urzędy skarbowe, banki, firmy ubezpieczeniowe. Wykorzystanie wspomnianych narzędzi jest niezbędne do zapewnienia prawidłowego funkcjonowania jednostki, niemniej jednak ze względu na okrojoną płaszczyznę działalności użytkowane w sposób marginalny w porównaniu z głównymi kanałami przepływu pracy.

Pozostałe formy przepływu pracy, takie jak odprawy kierownictwa (6\%), odprawy z podwładnymi (13\%), telefonia mobilna (13\%) i telefonia stacjonarna (6\%), wykorzystywane są głównie do komunikacji ze względu na brak możliwości archiwizacji procesów przepływy pracy. 
Badanie częstotliwości komunikacji z przełożonym (Wykres 12) nie rozgraniczało form oraz wykorzystywanych kanałów umożliwiających analizowany proces.

Wykres 12. Liczba osób komunikujących się z przełożonym

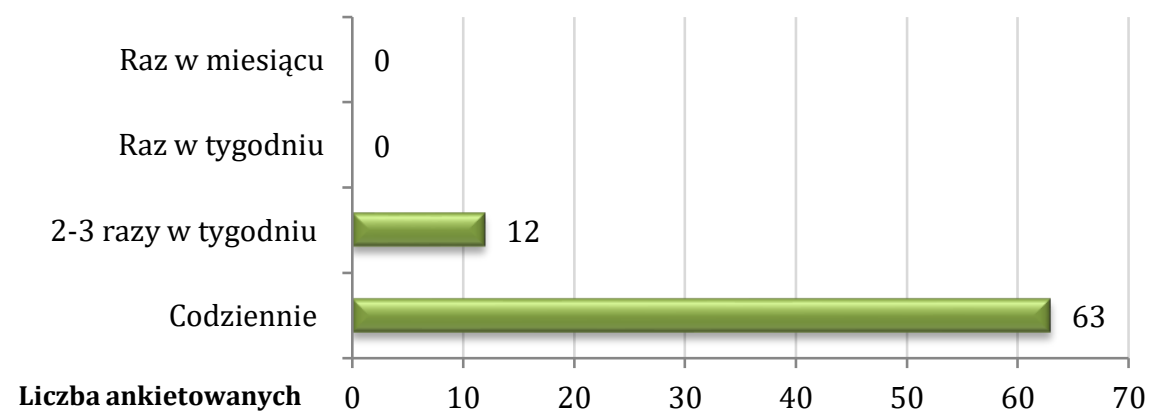

Źródło: Opracowanie własne

Respondenci wykazali, że sześćdziesiąt trzy osoby (84\%) z nich kontaktują się w czasie codziennych odpraw. Dwunastu ankietowanych (16\%) kontaktuje się z przełożonym kilka razy w tygodniu. Pracownicy pionu finansowego oraz logistyki, wykonując prace cykliczne, w większości przypadków pracują samodzielnie, kontaktują się z przełożonymi w związku z wymogiem zatwierdzania dokumentów sprawozdawczych lub finansowych.

Dalsza część badań wykazała wysoką świadomość i zrozumienie zależności efektywności pracy od przepływu informacji (Wykres 13). 
Wykres 13. Wpływ przepływu informacji na jakość pracy

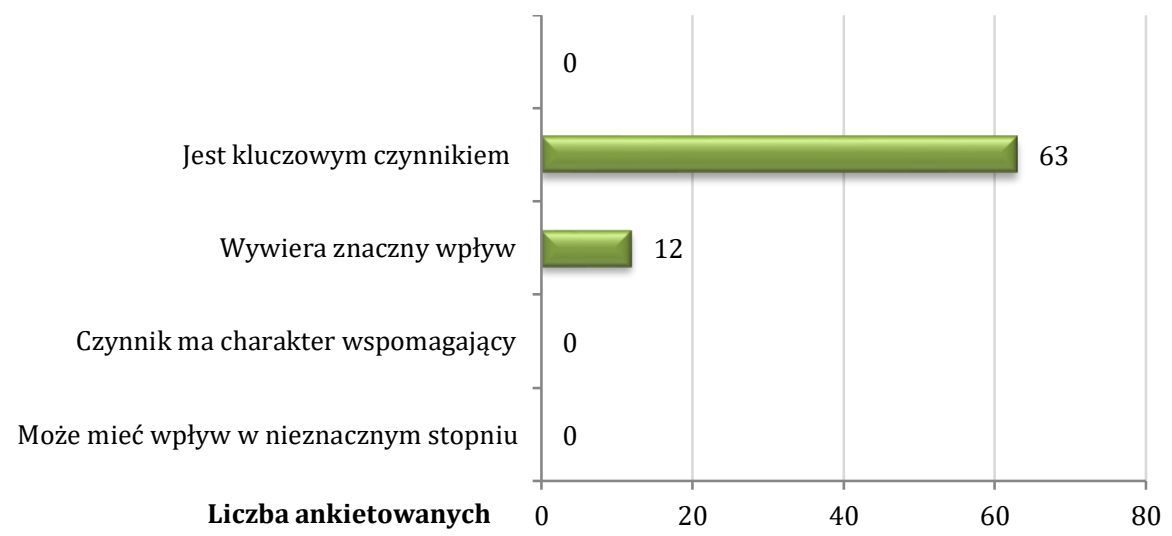

Źródło: Opracowanie własne

Świadomość kadry dowódczej dotycząca wpływu szybkości i jakości przepływu informacji wewnątrz instytucji sektora Obrony Narodowej na reputację i wizerunek jednostki organizacyjnej wykazała pełną aprobatę przytoczonej zależności wśród większość ankietowanych (84\%). Wyniki sondażu przedstawia Wykres 14.

Wykres 14. Wpływ przepływu informacji na wizerunek jednostki organizacyjnej

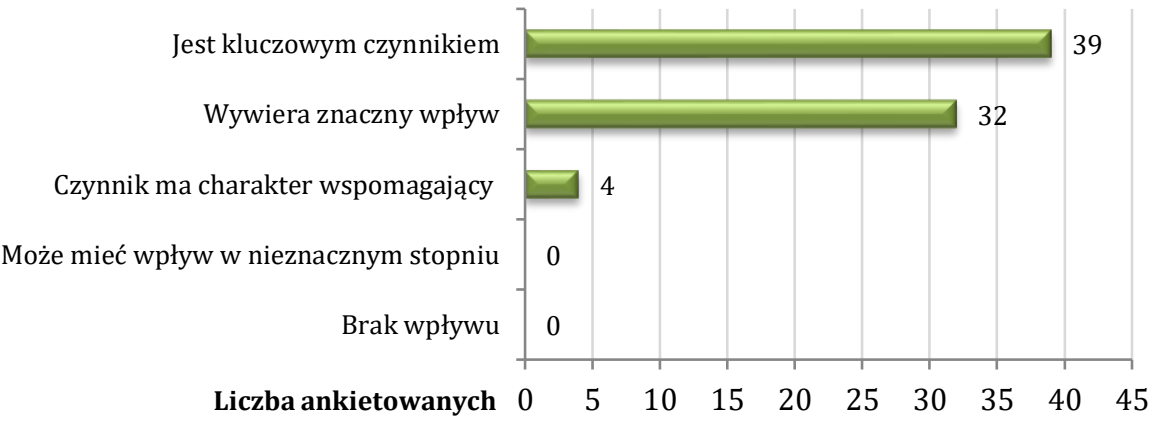

Źródło: Opracowanie własne

Analiza wyników badania dotyczącego barier komunikacyjnych w badanej instytucji (przedstawionego na Wykresie 15 umożliwia sformułowanie stwierdzenia, że według opinii trzydziestu ośmiu res- 
pondentów (45\%) główną barierą przepływu informacji jest hierarchiczna struktura organizacyjna. Dwudziestu respondentów (27\%) nie odczuwa barier komunikacyjnych. Piętnastu ankietowanych (20\%) jako główną barierę przepływu informacji wskazało brak umiejętności korzystania z narzędzi przepływu informacji takich, jak SI Arcus, poczta elektroniczna (Milnet-Z, Milnet-I). Sześciu ankietowanych jako główną barierę komunikacyjną wskazało brak umiejętności interpersonalnych.

Wykres 15. Bariery w przepływie informacji

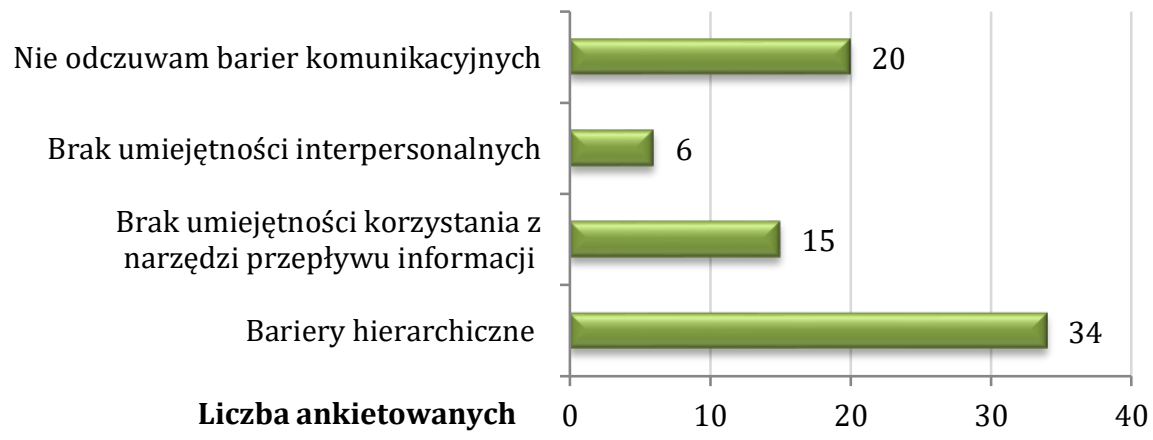

Źródło: Opracowanie własne

Do pozostałych czynników wpływających na efektywność procesu przepływu informacji zaliczono: brak zaufania, nieobecności w pracy, odpychający stosunek do współpracowników, pychę, brak chęci przekazywania i odbierania informacji, sceptyczne nastawienie oraz lekceważenie obowiązków.

Określając przyczynę złego przepływu informacji w jednostce, ankietowani wskazywali na bariery komunikacyjne między komórkami (16\%), brak podziału na informacje priorytetowe i mniej ważne (15\%), dużą rolę plotki w jednostce (14\%), przeładowanie informacjami (11\%) lub blokowanie informacji przez przełożonych (10\%) (Wykres 16). Do innych zaliczono niechęć ludzką, selektywny dobór informacji, zbyt dużą ilość kanałów przepływu informacji (4\%). 
Mirosław Dąbrowski - Usprawnienie przepływu informacji...

Wykres 16. Przyczyny złego przepływu informacji

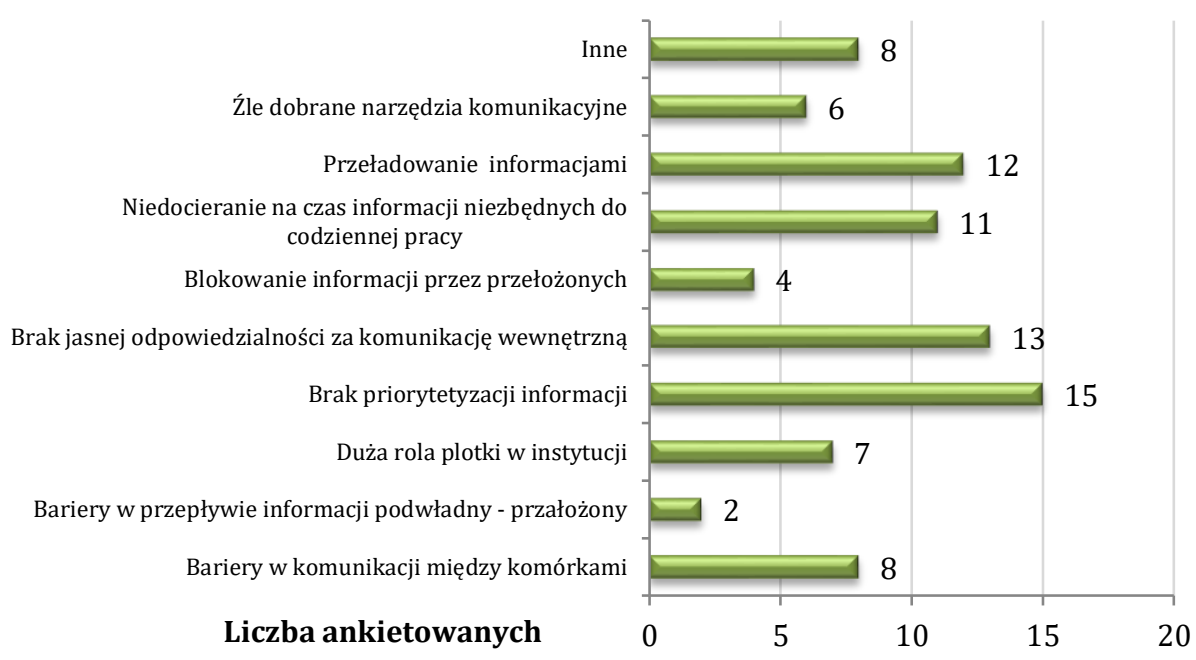

Źródło: Opracowanie własne.

Respondentów zapytano, czy przepływ informacji wewnątrz i na zewnątrz Jednostki wymaga poprawy. W odpowiedzi pięćdziesięciu dziewięciu ankietowanych (79\%) podzieliło pogląd potrzeby zmian dotyczących sposobów wykorzystywania użytkowanych kanałów wymiany informacji. Szesnastu ankietowanych (21\%) nie deklarowało potrzeby zmian w podmiotowym zakresie.

Wykres 17. Wyniki oceny potrzeb poprawy przepływu pracy w Jednostce

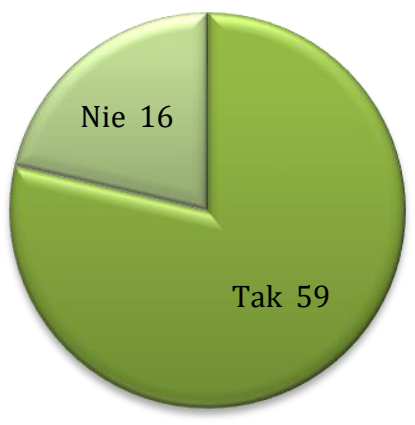

Źródło: Opracowanie własne 
Ostatnia część badań została poświęcona problematyce związanej z czynnikami wywierającymi niekorzystny wpływ na przepływ pracy w badanej instytucji. Pomimo wysokiej świadomości pracowników oraz możliwości wykorzystywania szerokiej gamy środków komunikacji sześćdziesiąt trzy procent ankietowanych wskazało w formularzach obszary przepływu pracy wymagające poprawy. Należą do nich:

- opóźnienia w przekazywaniu informacji,

- informacja zanika na pewnym poziomie lub dociera w postaci cząstkowej (niezależnie od użytego narzędzia),

- większa rola informacji nieformalnych,

- brak ogólnych informacji o działalności jednostki,

- powielanie tych samych pism z/do instytucji nadrzędnej,

- wymagana zmiana świadomości użytkowników dotycząca narzędzi przesyłu informacji z ukierunkowaniem na poprawę zdolności zbierania, organizowania i archiwizowania wiedzy,

- dublujące się informacje,

- kierowanie spraw do osób niewłaściwych merytorycznie,

- niestosowanie reguł automatycznej odpowiedzi w systemach SI ARCUS i MILNET-Z (nieobecności, wskazanie osoby zastępującej),

- brak przekierowań spraw do osób zastępujących na czas nieobecności osób odpowiedzialnych za realizację zadań,

- użytkownicy SI ARCUS nie wykorzystują w pełni możliwości stosowania łączników do danych pism, spraw czy dokumentów,

- brak konsekwencji stosowania danego narzędzia, np. odpowiedzi na pisma znajdujące się w SI ARCUS przesyłane poza systemem (pocztą elektroniczną w sieci MILNET-Z),

- brak wykorzystania dekretacji (np. informacji o zakończeniu sprawy czy notatek) lub dynamicznej ścieżki obiegu, co powoduje narastanie ilości pism stanowiących odpowiedzi na pisma zadekretowane,

- brak centralnego zarządzania,

- brak wspólnych zespołów projektowych, 
Mirosław Dąbrowski - Usprawnienie przepływu informacji...

- długa ścieżka przekazywania informacji,

- nieprzekazywanie informacji z odpraw,

- brak regularności przeglądania poczty,

- nieczytanie pism znajdujących się w SI ARCUS,

- bezmyślne przekazywanie do realizacji pionom nieodpowiedzialnym merytorycznie,

- niezrozumienie pojęcia wiedzy koniecznej,

- efektywność pracy tylko w przypadku pilnych spraw (im dłuższy termin realizacji tym mniejsza efektywność jej przekazywania),

- subiektywizm w ocenie ważności informacji,

- brak znajomości kompetencji,

- niewykorzystywanie w pełni narzędzi zarówno przepływu informacji, jak i planowania zadań (np. kalendarze),

- tendencja do przekazywania informacji telefonicznie,

- zbyt duża ilość informacji i kanałów informacyjnych,

- słaba koordynacja przedsięwzięć,

- brak rozliczania realizacji zadań,

- nieodbieranie telefonów.

Analizując uwagi ankietowanych, można stwierdzić, że część pracowników nie wykorzystuje w pełni potencjału systemów i narzędzi umożliwiających komunikację oraz wspierających przebieg pracy.

Podsumowując uzyskane wyniki badań, należy stwierdzić, że hipoteza badawcza, która brzmiała: „Należy przypuszczać, że najsłabszym ogniwem systemu przepływu pracy w badanej jednostce organizacyjnej jest czynnik ludzki" okazała się prawdziwa.

\section{Wnioski z przeprowadzonego audytu}

Zebrane informacje określają rozległy związek przyczynowo-skutkowy mający wpływ na formy komunikacji, przepływy informacji, a w konsekwencji przebiegi pracy w badanej jednostce. Analiza danych zgromadzonych w toku postępowania badawczego stała się podstawą sformułowania koncepcji usprawnienia procesów wewnętrznych zwią- 
zanych z przepływem informacji, pracy i dokumentów wykonawczych. W związku z powyższym uznano zasadnym:

1. Egzekwować wykorzystanie SI ARCUS wyłącznie do przekazywania dokumentów mających znaczenie archiwalne, wprowadzanie nieobecności, przekazywanie dokumentów do osoby zastępującej w przypadku dłuższych nieobecności, reagowanie na nieterminowość realizacji procesów.

2. Utworzyć w SI ARCUS obszar roboczy dedykowany dla komunikatów (ogłoszeń) bez oznaczenia stopnia realizacji, aby nie zaśmiecać skrzynek użytkowników.

3. Zwiększyć wiedzę i umiejętności posługiwania się elektronicznymi środkami komunikacji takimi, jak wideotelefony, procedury zestawiania wideokonferencji, udostępnianie prezentacji.

4. Wypracować jednolity schemat nazewnictwa i zawartości folderów udostępnianych użytkownikom dysku sieciowego celem usprawnienia wyszukiwania danych.

5. Wprowadzić procedurę „oddzwaniania” w przypadku zauważenia nieodebranych połączeń telefonicznych.

\section{Bibliografia:}

Adams K., Galanes G. J., Komunikacja w grupach, PWN, Warszawa 2008.

Babbie E., Badania społeczne w praktyce, PWN, Warszawa 2013.

Cornelissen J., Corporate Communications Theory and Practice, Sage, Londyn 2004.

Ćwiklicki M. Podstawy systemów workflow, Wyd. Akademii Ekonomicznej w Krakowie, Kraków 2006.

Eicher J., Sztuka komunikowania się, Wyd. Ravi, Łódź 1995.

Gawin B., Systemy informatyczne w zarzq̨dzaniu procesami workflow, PWN, Warszawa 2015.

Grajewski P., Organizacja procesowa, PWE, Warszawa 2007.

Kania K., Analiza procesów w adaptatywnych systemach workflow, „Prace Naukowe/Akademia Ekonomiczna w Katowicach" 2005. 
Mirosław Dąbrowski - Usprawnienie przepływu informacji...

Klonowski Z. J., Systemy informatyczne zarządzania przedsiębiorstwem. Modele rozwoju i właściwości funkcjonalne, Oficyna Wydawnicza Politechniki Wrocławskiej, Wrocław 2004.

Łobocki M., Wprowadzenie do metodologii badań pedagogicznych, Wyd. Impuls, Kraków 2012.

Maciejczak M., Zarządzanie procesami biznesowymi w teorii i praktyce, Wyd. PJWSTK, Warszawa 2011.

Martyniak Z., Teoretyczne podstawy systemów workflow, „Informatyka” 2000, nr 3.

Nowacki T. W., Korabiowska-Nowacka K., Baraniak B., Nowy słownik pedagogiki pracy, Wyd. WSP TWP, Warszawa 1999.

PN-EN ISO 9000:2006. Systemy zarzq̨dzania jakościq - Podstawy i terminologia, Warszawa 2006.

Puślecki W., Metody badań pedagogicznych, Wyd. TNOiK, Toruń 2012.

Sobkowiak B., Interpersonalne i grupowe komunikowanie się $w$ organizacji, Wyd. Forum Naukowe, Poznań-Wrocław 2005.

Stankiewicz J., Komunikowanie się w organizacji, Wyd. Astrum, Wrocław 2006.

Sztumski J., Wstęp do metodologii i technik badań społecznych, Wyd. Uniwersytetu Śląskiego, Katowice 2010.

Weinstein K., Komunikowanie się, [w:] D. M. Steward (red.), Praktyka kierowania, PWE, Warszawa 1994.

Winkler R., Zarzq̨dzanie komunikacjq w organizacjach zróżnicowanych kulturowo, Wyd. Wolters Kluwer, Kraków 2008.

Workflow Management Coalition. Terminology \& Glossary, https://www.yumpu.com/en/document/read/4582836/workflowmanagement-coalition-terminology-glossary 